NBER WORKING PAPER SERIES

\title{
MAPPING THE INTERCONNECTEDNESS BETWEEN EU BANKS AND SHADOW BANKING ENTITIES
}

\author{
Jorge Abad \\ Marco D'Errico \\ Neill Killeen \\ Vera Luz \\ Tuomas Peltonen \\ Richard Portes \\ Teresa Urbano \\ Working Paper 23280 \\ http://www.nber.org/papers/w23280 \\ NATIONAL BUREAU OF ECONOMIC RESEARCH \\ 1050 Massachusetts Avenue \\ Cambridge, MA 02138 \\ March 2017
}

The views expressed in this paper are our own, and do not necessarily reflect the views of the ESRB, EBA, their member institutions, or the National Bureau of Economic Research. Any remaining errors are our own. The authors would like to thank Claudia Guagliano, Olaf Weeken, Nicola Garbarino, Jan Klacso, the ESRB's Joint ATC-ASC Expert Group on Shadow Banking (JEGS), co-chaired by Steffen Kern and Richard Portes, and the ESRB's Advisory Scientific Committee (ASC) for helpful comments and discussion.

At least one co-author has disclosed a financial relationship of potential relevance for this research. Further information is available online at http://www.nber.org/papers/w23280.ack

NBER working papers are circulated for discussion and comment purposes. They have not been peer-reviewed or been subject to the review by the NBER Board of Directors that accompanies official NBER publications.

(C) 2017 by Jorge Abad, Marco D'Errico, Neill Killeen, Vera Luz, Tuomas Peltonen, Richard Portes, and Teresa Urbano. All rights reserved. Short sections of text, not to exceed two paragraphs, may be quoted without explicit permission provided that full credit, including (C) notice, is given to the source. 
Mapping the Interconnectedness between EU Banks and Shadow Banking Entities Jorge Abad, Marco D'Errico, Neill Killeen, Vera Luz, Tuomas Peltonen, Richard Portes, and Teresa Urbano

NBER Working Paper No. 23280

March 2017

JEL No. F65,G21,G23

\section{ABSTRACT}

This paper provides a unique snapshot of the exposures of EU banks to shadow banking entities within the global financial system. Drawing on a rich and novel dataset, the paper documents the cross-sector and cross-border linkages and considers which are the most relevant for systemic risk monitoring. From a macroprudential perspective, the identification of potential feedback and contagion channels arising from the linkages of banks and shadow banking entities is particularly challenging when shadow banking entities are domiciled in different jurisdictions. The analysis shows that many of the EU banks' exposures are towards non-EU entities, particularly USdomiciled shadow banking entities. At the individual level, banks' exposures are diversified although this diversification leads to high overlap across different types of shadow banking entities.

Jorge Abad

CEMFI

Casado del Alisal 5

28014 Madrid

Spain

jorge.abad@cemfi.edu.es

Marco D'Errico

University of Zurich

Plattenstrasse 14

8032 Zurich

Switzerland

marco.derrico@uzh.ch

Neill Killeen

European Systemic Risk Board Secretariat

Sonnemannstraße 20

D60314 Frankfurt am Main

Germany

neill.killeen@esrb.europa.eu

Vera Luz

European Banking Authority

Canary Wharf

London E14 5AA

United Kingdom

vera.luz@eba.europa.eu
Tuomas Peltonen

European Systemic Risk Board Secretariat

Sonnemannstraße 20

D60314 Frankfurt am Main

Germany

tuomas.peltonen@esrb.europa.eu

Richard Portes

London Business School

Regent's Park

London NW1 4SA

UNITED KINGDOM

and NBER

rportes@london.edu

Teresa Urbano

European Banking Authority

Canary Wharf

London E14 5AA

United Kingdom

teresa.urbano@eba.europa.eu 
"Policymakers and researchers need better models and data to understand the interconnections between the banking system and nonbank financial institutions."

- Stanley Fischer, December 2015

\section{Introduction}

The substantial growth of the shadow banking system in recent years has led to increased monitoring of this part of the financial sector. ${ }^{1}$ Given that 'shadow banking entities' can form part of complex financial intermediation chains which can also include banks and insurance corporations (Pozsar et al. 2013, Cetorelli 2014), understanding the nature of their linkages is important. The global financial crisis exposed shortcomings in the assessment of cross-sector and cross-border linkages in the financial system. The interaction of banks and insurance corporations with shadow banking entities led to the amplification of risks and spillovers which were transmitted across sectors and national borders. As shadow banking entities are subject to varying degrees of supervision, there was a lack of transparency and comprehensive macroprudential risk monitoring of their linkages and activities.

Owing to their heterogeneous activities, shadow banking entities can be direct counterparties to banks in a number of markets including derivative and funding markets. In addition, banks may be exposed to shadow banking entities through their common membership of a corporate group, through the provision of explicit or implicit backstops or indirectly through their common exposures to assets. ${ }^{2}$ Moreover, liquidity support provided by banks to off-balance sheet entities can further reinforce the link and potential contagion paths between the regular banking system and the shadow banking system (BCBS, 2015). As a result of these linkages, significant shocks

\footnotetext{
${ }^{1}$ For example, according to ESRB (2016a), a broad measure of the shadow banking system in the EU, comprising total assets of investment funds and other financial institutions (OFIs) represented approximately $36 \%$ of total EU financial sector assets at the end of 2015 and has grown by $22 \%$ since the end of 2012.

${ }^{2}$ See Claessens and Ratnovski (2014) and BCBS (2015) for a discussion on explicit and implicit backstops. The results of Gornicka (2016) lend support to the view that guarantees provided by sponsoring institutions are an important element of shadow banking. Furthermore, Clerc et al. (2016) examine the channels through which indirect contagion can spread across the financial system, including funding and asset markets, and highlight the role of the market price channel and information spillovers in propagating shocks.
} 
in the shadow banking system can have potential spillover effects on other parts of the financial system.

Since the global financial crisis, policymakers and regulators have sought to improve the monitoring framework for assessing the interconnectedness of the shadow banking system with the aim of mitigating systemic risks. The increasing size and complexity of the shadow banking system, coupled with its interconnectedness with the banking sector underlines the need for effective financial stability monitoring. At the global level, the Financial Stability Board (FSB) has coordinated efforts in improving data coverage for monitoring developments within the shadow banking system. ${ }^{3}$ At the European level, the European Systemic Risk Board (ESRB) has focused on monitoring potential financial stability risks, including those risks and negative externalities posed by entities and activities within the shadow banking system. ${ }^{4}$

While the interconnectedness between banks and shadow banking entities is often cited as a key financial stability concern, we are not aware of other studies which document and describe the nature of these linkages using EU bank and exposure-level information. Fischer (2015) points to the importance of mapping the linkages of shadow banking entities. He notes "an important area in need of development is economic modelling on interconnectedness, particularly on the interaction of shadow banking, banks and the broader financial system... such research could guide regulatory efforts to collect data and set policies to limit possible instabilities associated with interconnectedness." Furthermore, as described in ESRB (2016b), macroprudential policies beyond the banking sector should focus on the components of the financial system where systemic risks are higher. In order to assess the potential impact of spillovers, detailed analyses on the interconnections of different components of the financial system are required. Understanding the cross-sector and cross-border linkages will therefore equip policymakers and regulators with the necessary surveillance tools and can form a key input in the design of macroprudential

\footnotetext{
${ }^{3}$ See, for example, FSB (2011) which outlines the FSB's approach to strengthen the oversight and regulation of the shadow banking system. The FSB publish annual monitoring reports on the global shadow banking system. See FSB (2015).

${ }^{4}$ See ESRB (2016a) and Grillet-Aubert et al. (2016) for a description of the monitoring framework developed by the ESRB for assessing developments and risks within the EU shadow banking system.
} 
policies.

This paper contributes to the growing literature on the monitoring of shadow banking activities by providing a unique insight into the exposures of EU banks to shadow banking entities. In this way, the paper fills an important data gap and sheds new light by mapping for the first time these linkages using granular bank and exposure-level information. To the best of our knowledge, this is the first study which examines the linkages of EU banks to shadow banking entities at both the country and individual exposure level. In order to understand better the interconnectedness between EU banks and shadow banking entities and the underlying geography of risk ${ }^{5}$, the paper asks the following three questions. (1) Which EU banks are most exposed to shadow banking entities? (2) What types of shadow banking entities are EU banks exposed to? And (3) Where are these shadow banking entities domiciled?

In addition, the paper explores the potential contagion paths between the banking system and particular shadow banking entities drawing on the lessons from the financial crisis. For example, step-in risk exists for banks when they provide implicit guarantees and sponsor support to securitisation conduits, structured investment vehicles (SIVs) and money market funds (MMFs). The global financial crisis exposed how such backstops of shadow banking entities can have negative externalities for the banking system and can act as an additional transmission channel of risk (Acharya, Schnabl and Suarez, 2013; Bengtsson, 2013; Covitz, Liang and Suarez, 2013 and BCBS, 2015). Furthermore, we show that banks have rather diversified exposures towards shadow banking entities. However, such diversification leads to a high degree of overlap among banks' exposures to different types of shadow banking entities.

The rest of the paper is structured as follows. Section 2 describes the data used in our analysis and provides a brief overview of our data cleaning procedure. Section 3 outlines our analysis and examines the cross-sector and cross-border linkages of

\footnotetext{
${ }^{5}$ The cross-border analysis presented in this paper is based on the residency of the shadow banking entities. However, as noted by Lane (2016a), global financial intermediation means that the patterns of ultimate ownership are quite different to those suggested by the residence of investment vehicles. On the other hand, residence (domicile) is most directly relevant in determining the geographic locus of potential supervisory measures.
} 
banks' exposures to shadow banking entities before examining the level of concentration and overlap of the exposures. Section 4 discusses policy reforms which can assist in the monitoring of shadow banking interconnectedness while also highlighting the role of macroprudential policy in mitigating potential financial stability risks. Section 5 concludes.

\section{Data}

This section describes the data used in our analysis. In December 2015, the European Banking Authority (EBA) issued guidelines on the approach that institutions (banks and investment firms) should adopt for the purposes of setting appropriate individual and aggregate limits on exposures to shadow banking entities which carry out banking activities outside a regulated framework. ${ }^{6}$ In parallel to the development of the guidelines, the EBA conducted a data collection to understand better the volume and distributions of institutions' exposures to certain types of unregulated and 'lightly' regulated entities, and the potential impact of imposing limits to these exposures. ${ }^{7}$

A sample of institutions were asked to provide information regarding their exposures to counterparties considered as 'shadow banking entities'. 'Exposures' mean any asset or off-balance sheet item used in the calculation of capital requirements for credit risk under the standardised approach, without applying risk weights or degrees of risk. These data were collected at the highest level of consolidation in a Member State, or individual level if the consolidated level did not apply. Institutions were asked to calculate their exposures in the same way as any other exposure reported under the large exposures' regime set out in Part 4 of the Capital Requirements Regulation (CRR) and to report original exposures to individual counterparties, as well as the exposure before and after taking into account the effect of Credit Risk Mitigation (CRM) and

\footnotetext{
${ }^{6} \mathrm{https}$ // /www.eba.europa.eu/regulation-and-policy/large-exposures/guidelines-on-limits-onexposures-to-shadow-banking

${ }^{7}$ The definition of 'shadow banking entity' used for the purposes of the data collection was broader than the definition used in the final EBA guidelines, so as to capture as much information as possible and not to pre-empt future work by the EBA and/ or the European Commission on this topic.
} 
large exposures' exemptions, and also the percentage of the eligible capital. ${ }^{8}$ The exposures used in the analysis were after CRM and large exposures' exemptions. We do not in this paper consider institutions' liabilities to shadow banking entities. For the purposes of the data collection 'shadow banking entities' were defined as undertakings that met two conditions:

1. They carry out one or more credit intermediation activities. Here 'credit intermediation activities' means bank-like activities involving maturity transformation, liquidity transformation, leverage, credit risk transfer or similar activities.

2. They are not excluded undertakings (i.e. mainly undertakings that are subject to the CRD / CRR or are considered to be regulated in a similar way).

Institutions were asked to identify their counterparties by indicating their identifier code $^{9}$, name, and country of residence and to classify them in accordance with their underlying economic functions (i.e. activities rather than legal form). Information was collected on Undertakings for the Collective Investment in Transferable Securities (UCITS) MMFs, non-UCITS MMFs, non-MMF investment funds, finance companies, broker-dealers, credit insurers / financial guarantors, securitisations, non-equivalent banks / insurers and a residual category labelled as 'other' for institutions that can not be classified according to the types presented above. In addition, institutions were asked to indicate, to the best of their knowledge, whether a shadow banking entity was: (A) not supervised on a solo level, but supervised on a consolidated level in the Union; (B) not supervised on a solo level, but supervised on a consolidated level in a third country that has a regime at least equivalent to the one applied in the European Union, or (C) neither of the two.

The sample included 184 reporting institutions (169 banks and 15 investment firms) from 22 Member States, and the reference date for the reported data was 31 March

\footnotetext{
${ }^{8}$ Article 4(1), point 71 of regulation (EU) No.575/2013 defines 'eligible capital' as the sum of Tier 1 capital as referred to in Article 25 (of the same Regulation) and Tier 2 capital as referred to in Article 71 (of the same Regulation) that is equal to or less than one third of Tier 1 capital.

${ }^{9}$ In some cases, the identifier code provided were legal entity identifiers (LEIs) while others were internal codes.
} 
2015. ${ }^{10}$ In total, there were 107,621 individual exposures reported, which amounted to a total exposure of $€ 1,082$ billion. As reporting institutions could choose to report only the exposures to individual shadow banking entities with an exposure value after exemptions and CRM equal to or in excess of $0.25 \%$ of eligible capital, we must therefore use the subset of exposures equal to or above this threshold in order to undertake our analysis using the individual exposure level data. We do this in order to maintain a sample with information on the individual shadow banking counterparty which is necessary in order to undertake our analysis of the cross-sector and cross border linkages. For confidentiality reasons, the analysis did not identify individual countries that had a sample composed of three or fewer reporting institutions. ${ }^{11}$ EBA (2015) provides further details on the coverage of the sample in each Member State and further background information on the data collection process.

A significant cleaning procedure was applied to the data used in our analysis. As a first step, the national competent authorities (NCAs) made an initial assessment of the quality of the reported data prior to sending them to the EBA. Subsequently, the EBA performed several data quality checks in order to assess the completeness and consistency of the data and liaised with the NCAs where necessary. Some essential data cleaning was performed prior to conducting the analysis presented in this paper. For example, we exclude investment firms from our sample of reporting institutions and analyse only individual exposures of EU banks equal to or above $0.25 \%$ of banks' eligible capital. The subset of exposures that are equal to or above $0.25 \%$ of institutions' eligible capital represent 3,272 exposures ( $3 \%$ of the total number of exposures) with a total exposure amount of $€ 568$ billion (52\% of the total exposure amount for the full sample of reported exposures) and were reported by 139 EU banks. In addition, repeated shadow banking counterparties were identified based on duplicated counterparty IDs, duplicated counterparty names or on similar names (e.g. ABC Ltd as

\footnotetext{
${ }^{10}$ The participating Member States include Austria, Belgium, Cyprus, Czech Republic, Denmark, France, Germany, United Kingdom, Greece, Ireland, Italy, Latvia, Lithuania, Luxembourg, Malta, Netherlands, Norway, Poland, Portugal, Slovakia, Spain and Sweden.

${ }^{11}$ In the network graphs presented in Section 3, banks from countries who have less than 3 reporting institutions are labelled ' $X Z$ '.
} 
TABLE 1. Distribution of EU banks' exposures to shadow banking entities by country of reporting institution and domicile of shadow banking entity (in $€$ billion)

\begin{tabular}{lccccccccccccccc} 
B/SB & DE & FR & GB & IE & JE & KR & KY & LU & NL & RU & TR & US & O-EU & RW & Total \\
\hline AT & 0.2 & 0.0 & 0.3 & 0.2 & 0.0 & 0.1 & 0.2 & 0.2 & 0.3 & 0.8 & 0.1 & 0.6 & 3.1 & 0.7 & 6.8 \\
DE & 28.1 & 0.8 & 5.1 & 9.4 & 1.3 & 0.4 & 2.9 & 6.9 & 1.7 & 2.3 & 3.9 & 33.5 & 2.2 & 7.6 & 106.0 \\
FR & 0.5 & 16.2 & 3.7 & 1.9 & 0.2 & 2.9 & 4.9 & 1.4 & 2.0 & 0.5 & 0.5 & 30.1 & 2.7 & 10.9 & 78.3 \\
GB & 5.2 & 4.8 & 44.7 & 19.8 & 14.7 & 7.8 & 24.9 & 12.0 & 3.5 & 1.5 & 3.0 & 84.0 & 4.0 & 54.5 & 284.4 \\
IT & 0.0 & 1.3 & 2.8 & 2.6 & 0.4 & 1.3 & 0.0 & 2.5 & 0.1 & 2.1 & 7.5 & 0.5 & 2.9 & 2.9 & 26.8 \\
LU & 1.1 & 0.7 & 0.8 & 0.4 & 0.0 & 0.0 & 0.3 & 2.5 & 3.0 & 0.2 & 0.0 & 0.1 & 1.0 & 0.4 & 10.4 \\
O-EU & 0.5 & 1.4 & 1.5 & 1.1 & 0.5 & 2.3 & 3.2 & 3.3 & 3.2 & 2.9 & 4.5 & 2.8 & 12.8 & 6.7 & 46.8 \\
\hline Total & 35.5 & 25.1 & 59.0 & 35.4 & 17.0 & 14.8 & 36.4 & 28.8 & 13.8 & 10.4 & 19.5 & 151.5 & 28.7 & 83.5 & 559.4
\end{tabular}

Source: Authors' calculations based on EBA (2015), Report on institutions' exposures to 'shadow banking entities', December 2015. Note: Data refer to individual exposures equal to or above 0.25 per cent of eligible capital. Country labels on the left hand side of the chart refer to the country of domicile of the reporting institution. Country labels along the top of the chart refer to country of domicile of shadow banking entity. O-EU refers to other EU countries while $R W$ refers to the rest of the world. The chart excludes investment firms and exposures greater than $25 \%$ of the institution's eligible capital (the large exposure limit).

TABLE 2. Distribution of EU banks' exposures to shadow banking entities by country of reporting institution and domicile of shadow banking entity (as a \% of GDP of country of reporting bank)

\begin{tabular}{lccccccccccccccc} 
B / SB & DE & FR & GB & IE & JE & KR & KY & LU & NL & RU & TR & US & O-EU & RW & Total \\
\hline AT & 0.1 & 0.0 & 0.1 & 0.0 & 0.0 & 0.0 & 0.1 & 0.1 & 0.1 & 0.3 & 0.0 & 0.2 & 1.0 & 0.2 & 2.2 \\
DE & 1.0 & 0.0 & 0.2 & 0.3 & 0.0 & 0.0 & 0.1 & 0.3 & 0.1 & 0.1 & 0.1 & 1.2 & 0.1 & 0.3 & 3.9 \\
FR & 0.0 & 0.8 & 0.2 & 0.1 & 0.0 & 0.1 & 0.2 & 0.1 & 0.1 & 0.0 & 0.0 & 1.5 & 0.1 & 0.5 & 3.8 \\
GB & 0.3 & 0.3 & 2.4 & 1.0 & 0.8 & 0.4 & 1.3 & 0.6 & 0.2 & 0.1 & 0.2 & 4.4 & 0.2 & 2.9 & 15.0 \\
IT & 0.0 & 0.1 & 0.2 & 0.2 & 0.0 & 0.1 & 0.0 & 0.2 & 0.0 & 0.1 & 0.5 & 0.0 & 0.2 & 0.2 & 1.7 \\
LU & 2.4 & 1.5 & 1.8 & 1.0 & 0.0 & 0.0 & 0.6 & 5.5 & 6.5 & 0.5 & 0.0 & 0.1 & 2.1 & 0.8 & 22.9 \\
O-EU & 0.0 & 0.0 & 0.0 & 0.0 & 0.0 & 0.1 & 0.1 & 0.1 & 0.1 & 0.1 & 0.1 & 0.1 & 0.3 & 0.1 & 1.1 \\
\hline Total & 0.3 & 0.2 & 0.5 & 0.3 & 0.1 & 0.1 & 0.3 & 0.2 & 0.1 & 0.1 & 0.1 & 1.2 & 0.2 & 0.6 & 4.3
\end{tabular}

Source: Authors' calculations based on EBA (2015), Report on institutions' exposures to "shadow banking entities", December 2015. Note: Data refer to individual exposures equal to or above 0.25 per cent of eligible capital. Country labels on the left hand side of the chart refer to the country of domicile of the reporting institution. Country labels along the top of the chart refer to country of domicile of shadow banking entity. $O-E U$ refers to other EU countries while $R W$ refers to the rest of the world. The chart excludes investment firms and exposures greater than $25 \%$ of the institution's eligible capital (the large exposure limit). 
opposed to ABC Limited). Similarly, as shown in EBA (2015), 19\% of the shadow banking counterparties by value of exposures were not identified by country of residence. Therefore, we manually clean and match these data to reduce this data limitation to $1 \%$ of exposures. This allows us to map the geography of the exposures using network analysis techniques.

In order to explore the characteristics of EU banks (e.g. total assets, number of subsidiaries) in our sample, we also merge the EBA's data with bank-level information taken from Bureau van Dijk's Orbis database. Next, we exclude individual exposures greater than $25 \%$ of banks' eligible capital which corresponds to the large exposure limit in Article 395 of the CRR. ${ }^{12}$ This leaves a final sample of 131 banks and 3,182 individual exposures. To gain an overview of the data, Table 1 shows that the total exposures amount to approximately $€ 560$ billion, representing $4.3 \%$ of EU GDP (Table 2) with significant heterogeneity across countries.

\section{Mapping of EU banks' exposures to shadow banking entities}

This section provides a unique analysis of EU banks' exposures to shadow banking entities. First, it examines the characteristics of the EU banks which have exposures to shadow banking entities. It then analyses the types of shadow banking entities to which EU banks are exposed before proceeding to an analysis of the cross-border nature of these linkages. This section concludes with an analysis of the concentration and overlap of EU banks' exposures to shadow banking entities.

\subsection{Which? EU banks' exposures to shadow banking entities}

Our analysis of EU banks' exposures to shadow banking entities first examines the characteristics of the banks involved. As described in Section 2, we complement the

\footnotetext{
${ }^{12}$ We do this to exclude outliers in the data. Moreover, in line with the large exposure limit, the sum of all the exposure values of a bank to a single counterparty or to a group of connected counterparties must not be higher than $25 \%$ of banks' eligible capital.
} 
EBA data using information taken from Bureau van Dijk's Orbis database. ${ }^{13}$ Total assets of banks in our sample amount to $€ 27$ trillion. The data show that $23 \%$ of the banks in the EBA sample are from Germany, 13\% are from the UK and 3\% are banks from France. Weighting by their balance sheet size, however, shows that UK banks account for $39 \%$ of the total assets of the banks in our sample, while German and French banks account for $11 \%$ and $21 \%$, respectively. As noted in EBA (2015), the banks in our sample cover $56 \%$ of total assets of the EU financial sector, although the coverage is heterogeneous across countries. For example, French and UK banks account for $75 \%$ and $85 \%$ of their respective financial sectors (see EBA, 2015), while Irish banks in our sample account for only $6 \%$ of the Irish financial sector. However, as described in FSB (2015), approximately $80 \%$ of the Irish financial sector consists of entities outside of the regular banking system. Reflecting this, Irish banks in our sample account for approximately $60 \%$ of the Irish banking sector.

\section{TABLE 3. EU banks' exposures to shadow banking entities as a \% of banks' (by country) eligible capital}

\begin{tabular}{lccccccccccccccc} 
B / SB & DE & FR & GB & IE & JE & KR & KY & LU & NL & RU & TR & US & O-EU & RW & Total \\
\hline AT & 2.2 & 0.0 & 4.4 & 2.0 & 0.0 & 1.2 & 2.4 & 2.8 & 3.5 & 10.3 & 1.5 & 7.0 & 39.1 & 8.9 & 85.1 \\
DE & 28.6 & 0.8 & 5.2 & 9.5 & 1.3 & 0.4 & 3.0 & 7.0 & 1.7 & 2.3 & 4.0 & 34.1 & 2.3 & 7.7 & 107.7 \\
FR & 0.4 & 12.7 & 2.9 & 1.5 & 0.1 & 2.3 & 3.9 & 1.1 & 1.6 & 0.4 & 0.4 & 23.7 & 2.1 & 8.6 & 61.7 \\
GB & 1.4 & 1.3 & 11.9 & 5.3 & 3.9 & 2.1 & 6.7 & 3.2 & 0.9 & 0.4 & 0.8 & 22.4 & 1.1 & 14.5 & 75.9 \\
IT & 0.0 & 3.4 & 7.5 & 6.9 & 1.0 & 3.5 & 0.0 & 6.6 & 0.4 & 5.6 & 20.1 & 1.3 & 7.7 & 7.7 & 71.6 \\
LU & 24.7 & 15.0 & 18.2 & 10.1 & 0.0 & 0.4 & 5.9 & 56.1 & 66.6 & 5.2 & 0.0 & 1.4 & 21.9 & 8.6 & 234.2 \\
O-EU & 0.9 & 2.7 & 2.9 & 2.1 & 1.0 & 4.4 & 6.1 & 6.3 & 6.1 & 5.5 & 8.4 & 5.3 & 24.2 & 12.6 & 88.5 \\
\hline Total & 5.1 & 3.6 & 8.4 & 5.0 & 2.4 & 2.1 & 5.2 & 4.1 & 2.0 & 1.5 & 2.8 & 21.6 & 4.1 & 11.9 & 79.6
\end{tabular}

Source: Authors' calculations based on EBA (2015), Report on institutions' exposures to 'shadow banking entities', December 2015. Note: Data refer to individual exposures equal to or above 0.25 per cent of eligible capital. Country labels on the left hand side of the chart refer to the country of domicile of the reporting institution. Country labels along the top of the chart refer to country of domicile of shadow banking entity. O-EU refers to other EU countries while $R W$ refers to the rest of the world. The chart excludes investment firms and exposures greater than $25 \%$ of the institution's eligible capital (the large exposure limit).

In terms of exposures to shadow banking entities, UK banks have a total of 779 exposures (24\% of the total in our sample), accounting for $€ 284$ billion (slightly more

\footnotetext{
${ }^{13}$ This allows us to match balance sheet data on total assets for 123 out of the 131 banks in our sample.
} 
FIGURE 1. Number of counterparties and total exposures by bank (EUR million)

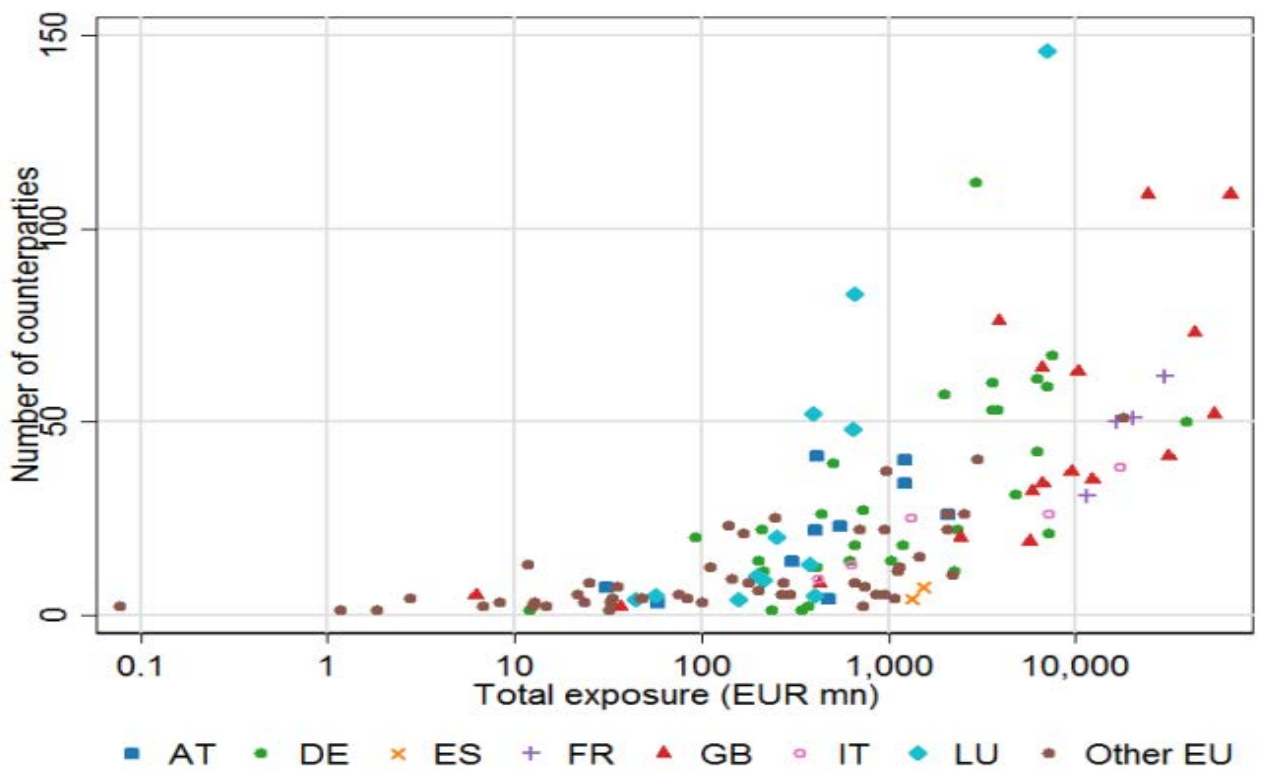

Source: Authors' calculations based on EBA (2015), Report on institutions' exposures to "shadow banking entities", December 2015. Note: Data refer to individual exposures equal to or above 0.25 per cent of eligible capital of the reporting bank. The chart excludes investment firms and exposures greater than $25 \%$ of the institution's eligible capital (the large exposure limit).

FIGURE 2. Number of counterparties and total exposures by bank (\% of eligible capital)

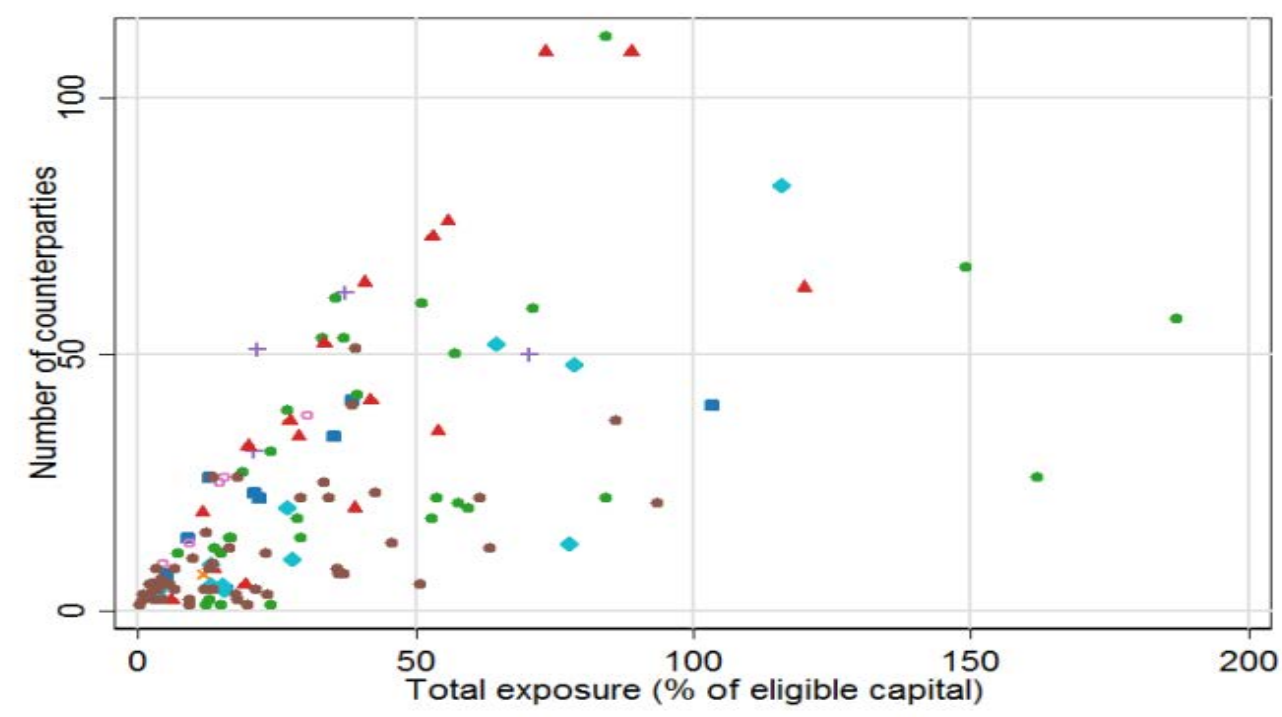

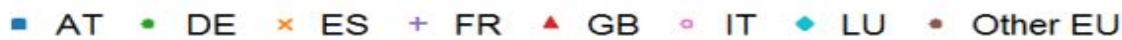

Source: Authors' calculations based on EBA (2015), Report on institutions' exposures to 'shadow banking entities', December 2015. Note: Data refer to individual exposures equal to or above 0.25 per cent of eligible capital of the reporitng bank. The chart excludes investment firms and exposures greater than $25 \%$ of the institution's eligible capital (the large exposure limit). 
than half of the total amount and 15\% of UK's GDP). German and French banks have a total of 939 and 194 exposures (29\% and 6\% of the total), accounting for $€ 106$ billion and $€ 78$ billion (roughly $4 \%$ of their countries' GDP), respectively. The exposures of UK banks represent $76 \%$ of their aggregate eligible capital, 108\% for German banks and $62 \%$ for French banks (Table 3). A comprehensive breakdown of the exposures by sector and country of the shadow banking institutions is presented in the Sections 3.2 and 3.3.

Turning to the bank-level data, Figures 1 and 2 illustrate the positive relationship between the number of counterparties of each bank and their total exposure to shadow banking entities (both measured in $€$ millions and as a \% of their eligible capital). Following Cetorelli and Goldberg (2014), we construct a measure of banks' geographic complexity and check whether more complex banks tend also to have a greater geographical diversification of their exposures to shadow banking entities. ${ }^{14}$ As in their paper, this complexity measure is constructed using data on the location of the subsidiaries of the banks in our sample. Figure 3 shows that the relationship between the banks' geographic diversification of exposures to shadow banks and their geographic complexity is positive, and it is also correlated with the banks' size (depicted as the size of each of the circles). A more comprehensive analysis of the geography of the exposures is presented in Section 3.3.

\subsection{What? The types of shadow banking counterparties}

Table 4 shows that EU banks are exposed to many different types of shadow banking entities. ${ }^{15}$ Importantly, there are significant differences in the business models and risk profiles across entities. For example, entities such as non-equivalent banks / insurers and credit insurers / financial guarantors are less likely to be captured in shadow banking surveillance exercises depending on the definition of shadow banking employed.

\footnotetext{
${ }^{14}$ The geographic complexity measure is constructed as a Herfindahl concentration index. See Cetorelli and Goldberg (2014) for further details.

${ }^{15}$ Regarding non-MMF investment funds, the data are even more granular and are split into hedge funds, equity funds, real-estate funds, fixed income funds, other investment funds and 'not identified' funds.
} 


\section{FIGURE 3. Geographic diversification of EU banks' exposures to shadow banking entities and banks' geographic complexity}

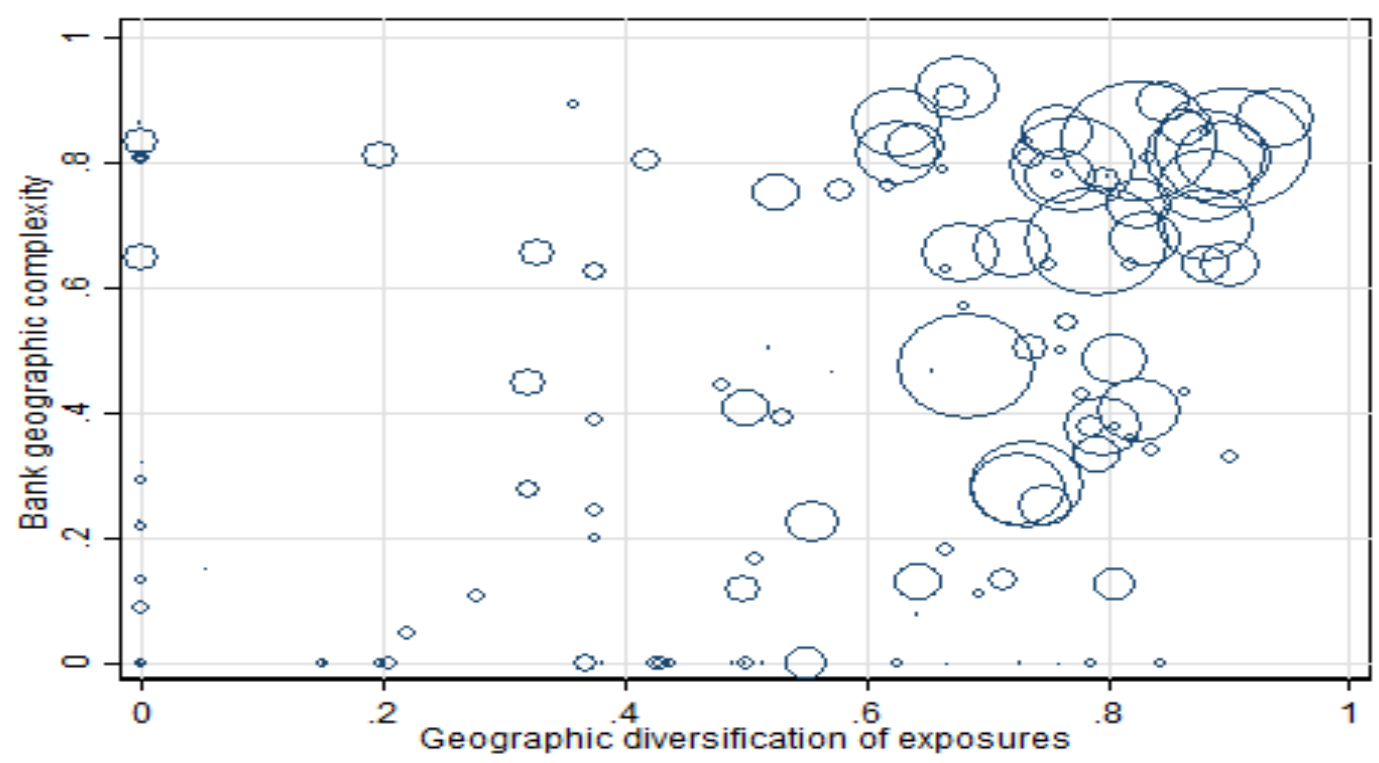

Source: Authors' calculations based on EBA (2015), Report on institutions' exposures to 'shadow banking entities', December 2015. Note: Data refer to individual exposures equal to or above 0.25 per cent of eligible capital. The chart excludes investment firms and exposures greater than $25 \%$ of the institution's eligible capital (the large exposure limit)

The final dataset we employ shows that EU banks had around 65\% of their exposures to securitisations (26\%), investment funds other than MMFs (22\%) and finance companies (18\%). Regarding the top five exposures by type and country of domicile of the shadow banking entities (in EUR billions), Table 4 highlights that EU banks are most heavily exposed to finance companies domiciled in the US, followed by US securitisation vehicles, 'other' US shadow banking entities, securitisation vehicles domiciled in Ireland and US non-MMF investment funds.

While some of the linkages between banks and shadow banking entities may simply capture standard financial intermediation flows, others may reflect the increased complexity of intermediation chains across the financial system. In this paper we do not explore the motives for the linkages between banks and shadow banking entities. Rather, taking a macroprudential perspective, we document the different types of linkages and consider which are the most relevant for systemic risk monitoring. For example, as the financial crisis showed, a fundamental source of shadow banking risk relates to regulatory arbitrage across borders and sectors, including from the bank- 
TABLE 4. Distribution of EU banks' exposures to shadow banking entities by country of domicile and type of shadow banking entity (weighted by size of exposure)

\begin{tabular}{|c|c|c|c|c|c|c|c|c|c|c|}
\hline Country / type & 1 & 2 & 3 & 4 & 5 & 6 & 7 & 8 & 9 & Total \\
\hline $\mathrm{DE}$ & 0.0 & 0.0 & 3.7 & 1.0 & 0.0 & 0.0 & 1.2 & 0.0 & 0.4 & 6.3 \\
\hline ES & 0.0 & 0.0 & 0.0 & 0.3 & 0.0 & 0.1 & 0.3 & 0.0 & 0.1 & 0.7 \\
\hline FR & 0.7 & 0.0 & 0.5 & 0.6 & 0.0 & 0.0 & 2.2 & 0.0 & 0.4 & 4.5 \\
\hline GB & 0.0 & 0.4 & 2.5 & 2.0 & 0.4 & 0.5 & 2.2 & 0.0 & 2.4 & 10.5 \\
\hline IE & 0.0 & 0.0 & 0.8 & 0.7 & 0.0 & 0.0 & 4.5 & 0.0 & 0.3 & 6.3 \\
\hline LU & 0.3 & 0.0 & 2.3 & 0.7 & 0.2 & 0.0 & 1.2 & 0.0 & 0.4 & 5.2 \\
\hline NL & 0.0 & 0.0 & 0.2 & 0.6 & 0.0 & 0.0 & 1.5 & 0.0 & 0.1 & 2.5 \\
\hline O-EU & 0.1 & 0.0 & 2.0 & 1.4 & 0.0 & 0.0 & 0.4 & 0.1 & 0.3 & 4.4 \\
\hline HK & 0.1 & 0.0 & 0.5 & 0.0 & 0.6 & 0.0 & 0.0 & 0.0 & 0.1 & 1.3 \\
\hline $\mathrm{JE}$ & 0.0 & 0.0 & 0.2 & 0.1 & 0.0 & 0.0 & 2.7 & 0.0 & 0.0 & 3.0 \\
\hline JP & 0.0 & 0.0 & 0.2 & 0.1 & 0.6 & 0.0 & 0.0 & 0.4 & 0.2 & 1.5 \\
\hline KR & 0.0 & 0.0 & 0.0 & 0.2 & 0.0 & 0.0 & 0.0 & 1.9 & 0.5 & 2.6 \\
\hline KY & 0.0 & 0.0 & 3.4 & 0.7 & 0.0 & 0.0 & 1.8 & 0.1 & 0.5 & 6.5 \\
\hline RU & 0.0 & 0.0 & 0.0 & 0.1 & 0.0 & 0.0 & 0.0 & 1.7 & 0.1 & 1.9 \\
\hline TR & 0.0 & 0.0 & 0.0 & 0.4 & 0.0 & 0.0 & 0.0 & 3.0 & 0.0 & 3.5 \\
\hline US & 0.7 & 0.2 & 4.0 & 8.2 & 0.3 & 0.3 & 7.1 & 1.6 & 4.7 & 27.1 \\
\hline RW & 0.0 & 0.1 & 1.9 & 1.2 & 0.6 & 0.6 & 0.8 & 4.4 & 2.5 & 12.1 \\
\hline Total & 2.0 & 0.9 & 22.3 & 18.2 & 2.8 & 1.4 & 26.2 & 13.3 & 13.0 & 100.0 \\
\hline
\end{tabular}

Source: Authors' calculations based on EBA (2015), Report on institutions' exposures to 'shadow banking entities', December 2015. Note: Data refer to individual exposures equal to or above 0.25 per cent of eligible capital. Country labels on the left hand side of the chart refer to the country of domicile of the shadow banking entity. O-EU refers to other EU countries while $R W$ refers to the rest of the world. The numbers along the top of the chart refer to the type of shadow banking entity as in EBA (2015). 1 = UCITS MMF; 2 = Non-UCITS MMF; 3 = Non-MMF investment fund; 4 = finance companies; 5 = broker-dealers; $6=$ credit insurers / financial guarantors; $7=$ securitisation; $8=$ non-equivalent banks / insurers; $9=$ other. 
ing system. Fragmented regulatory regimes and a lack of information and disclosure can lead to regulatory arbitrage and can impede systemic risk monitoring of shadow banking interconnectedness.

A growing number of studies including Adrian and Ashcraft (2012) and Adrian, Ashcraft and Ceterolli (2013) document some of the incentives of financial institutions to avoid taxes, accounting rules and capital requirements. Adrian (2014) highlights regulatory and tax arbitrage as a potential motivation for the increasing role of shadow banking entities within the financial system. Similarly, Acharya, Schnabl and Suarez (2013) show that regulatory arbitrage was an important motive in the setting up of asset-backed commercial paper conduits. They find that such shadow banking entities had insufficient risk transfer as losses remained with the banks themselves. The banks had structured the guarantees to these entities so as to reduce regulatory capital requirements. The results of Gornicka (2016) also provide insights into the role of guarantees between banks and shadow banking entities, while Claessens and Ratnovski (2014) consider the reliance on backstops as a crucial feature of shadow banking.

Our data also show that $13 \%$ of EU banks' total exposures are to entities that could not be further identified and are labelled as 'other' shadow banking entities, highlighting the information limitations for some types of entities. Moreover, the data illustrate that the reporting banks possess limited information about the supervisory treatment of their shadow banking counterparties. By value of the exposures, almost $90 \%$ of the shadow banking counterparties were reported as either not supervised or not further identified by the reporting institution.

The existence and scope of regulatory regimes for shadow banking entities can vary both across but also within jurisdictions. This further reinforces the need for a detailed mapping of the cross-sector linkages. For example, consider the three types of shadow banking entities that EU banks are most exposed to: non-MMF investment funds, finance companies, and securitisations. While investment funds and fund managers are regulated and supervised in the EU through the UCITS and Alternative Investment Fund Managers Directive (AIFMD) respectively, there is large variation with respect 
to the regulatory treatment of finance companies and securitisations. Similarly, the regulatory treatment of investment funds, finance companies and securitisations may vary across jurisdictions outside the EU and may not be equivalent to EU applicable regimes. In light of these differences, we proceed by examining the types of shadow banking entities that EU banks are most exposed to and discuss potential financial stability risks associated with the business models or particular features of these entities.

Securitisations: This classification includes securitisation-based credit intermediation and funding of financial entities including CLOs, ABCP and SIVs. These entities played a disruptive role during the global financial crisis and have since received increased attention from researchers, policymakers and regulators alike. Regarding empirical studies, Acharya, Schnabl and Suarez (2013) show that such shadow banking entities had insufficient risk transfer during the crisis as losses remained with the banks themselves. Similarly, Covitz, Liang and Suarez (2013) document runs in the ABCP market. ${ }^{16}$ Their findings suggest that banks may be exposed to liquidity vulnerabilities through their implicit and explicit support of ABCP programmes or other conduits in the shadow banking system.

The interconnectedness of banks and shadow banking entities can lead to stepin risk when banks provide sponsor support to securitisation conduits and SIVs. As noted by BCBS (2015), the majority of securitisation vehicles and SIVs that encountered difficulties during the global financial crisis were supported by banks through liquidity provisions that the banks were not contractually obliged to make. In most cases, the sponsoring bank absorbed the losses of these vehicles, which resulted in bringing these shadow banking entities back onto the bank's balance sheet. Therefore, although crosssector interconnectedness can be unobservable or indirect in nature, step-in risk may still exist.

Our data show that, by value of exposure, approximately $27 \%$ of EU banks' expo-

\footnotetext{
${ }^{16}$ From a financial stability perspective, bank step-in risks can refer to either liquidity risk (i.e. runs) or solvency issues (i.e. losses) or both. Covitz, Liang and Suarez (2013) define a run on a commercial paper program as when short-term creditors refuse to roll over their positions. Similarly, Acharya, Schnabl and Suarez (2013) examine whether an investor that was holding ABCP at the start of the financial crisis suffered losses by not rolling over maturing ABCP.
} 
sures to securitisations are to entities domiciled in the US, while they also have significant exposures to entities domiciled in Ireland, Jersey, France and the United Kingdom. Moreover, EBA (2014) points to an inconsistent regulatory treatment of securitisation vehicles across EU Member States. In some Member States, securitisation vehicles are subject to solo prudential requirements, while in others they remain outside the regulatory perimeter. Table 4 shows that $36 \%$ of EU banks' exposures to securitisation vehicles are to entities which are domiciled in jurisdictions where no solo prudential requirements are in place (e.g. Ireland, Luxembourg, the Netherlands and the United Kingdom). Similar to finance companies, however, securitisation vehicles may be prudentially consolidated in large banking groups or may be subject to some form of regulatory or statistical oversight. For example, euro area securitisation entities known as financial vehicle corporations (FVCs) have been subject to quarterly ECB statistical reporting obligations since the end of 2009. In addition, jurisdictions such as Ireland have recently introduced new reporting requirements on a wider sample of SPVs in order to understand better their activities and their associated cross-sector and crossborder linkages. ${ }^{17}$ The exposures of EU banks to securitisations captured in our final dataset may also include retained transactions, namely those that are not placed in the market but held on balance sheet and used for collateral purposes in central bank refinancing operations.

Finance companies: Finance companies comprise entities that engage in loan provision that is dependent on short-term funding and include entities such as leasing companies and finance companies. Pozsar et al. (2013) document the role played by finance companies in the shadow banking system, which typically involves loan origination funded through commercial paper or medium term notes. Similarly, GrilletAubert et al. (2016) note that these entities are relevant from a shadow banking perspective if they engage in credit intermediation outside of the regulatory perimeter and are interconnected with the regular banking system.

Regarding their regulatory treatment, EBA (2014) highlights the fragmentation of

\footnotetext{
${ }^{17}$ See Godfrey, Killeen and Moloney (2015).
} 
national regulatory regimes applicable to finance companies in the EU. For example, in some EU Member States, finance companies are subject to solo prudential requirements (e.g. France, Italy, Portugal and Spain), whereas in others they are not (e.g. Belgium, Bulgaria, Czech Republic, Denmark, Greece, Ireland, Lithuania, Latvia, the Netherlands, Slovakia, the United Kingdom). As shown in Table 4, 45\% of EU banks' exposures to finance companies (in $€$ billions) are towards US-domiciled entities, while a significant share of exposures to finance companies within the EU relate to jurisdictions that do not report solo prudential regulatory requirements for finance companies in EBA (2014). It is important to note, however, that some of the finance companies domiciled in these jurisdictions may be consolidated in large banking groups. As explained below, however, a lack of data on the supervisory treatment of these entities does not allow for such a detailed assessment.

Non-MMF investment funds: Our data include categories for hedge funds, equity funds, real-estate funds, fixed income funds, other investment funds and 'not identified' funds. There is a large diversity of business models within the sector which affects their susceptibility to financial stability risks, including run risk. For example, alternative investment funds like hedge funds can employ significant leverage and are therefore relevant for shadow banking monitoring, while others such as equity funds are less exposed to shadow banking risks. As noted by Grillet-Aubert et al (2016), owing to the diversity of the investment fund sector, the underlying liability structures, investor profiles and regulatory constraints should be assessed when monitoring risks within this sector.

More recently, liquidity and leverage within the investment fund sector and business models such as open-ended real estate funds and high-yield corporate bond funds have attracted increasing attention owing to their potential for amplifying financial stability risks. Therefore, understanding the exposures of EU banks to these types of investment funds is important. Overall, our data show that $22 \%$ of total exposures of EU banks are to non-MMF investment funds with many of these entities domiciled in the US, Cayman Islands, Germany, Luxembourg and the United Kingdom. 


\subsection{Where? The cross-border exposures of EU banks to shadow bank- ing entities}

Next, we explore the cross-border nature of the exposures of EU banks to shadow banking entities to understand better the internationalisation of the shadow banking system and the cross-border complexity of the linkages. Our data highlight the global and cross-border nature of the interconnectedness of shadow banking entities, as approximately $60 \%$ of EU banks' total exposures to shadow banking entities are towards non-EU domiciled entities. In particular, these data show the strong links between EU banks and US-domiciled shadow banking entities, which account for approximately $27 \%$ of the total exposures in our final dataset. A number of studies including, for example, IMF (2014) and Maes (2014) highlight the interaction of EU banks and USdomiciled shadow banking entities during the financial crisis.

Figures 4 and 5 map the international exposures of EU banks to shadow banking entities using granular bank-level and individual exposure level information. The green nodes represent the reporting banks, while their size is determined by the number of individual counterparties or shadow banking entities to which they are exposed to (degree centrality). Orange nodes represent non-EU-domiciled shadow banking entities while the purple nodes represent EU domiciled shadow banking entities. Moreover, the orange links in the network in Figure 4 show that EU banks have a large number of exposures to non-EU domiciled shadow banking entities. The purple links show that EU banks have exposures to a number of EU domiciled shadow banking entities while the blue links represent domestic exposures (EU bank exposure to a shadow banking entity domiciled in the same country as the bank).

Figure 5 shows a network where the positioning is identical to the network presented in Figure 4. However, the node size in Figure 5 is proportional to total exposures (i.e. sum of all individual exposures) while the colour of links range from green (smaller exposures) to orange (larger exposures) depending on the size of the individual exposure in $€$ billions. Taken together, these network graphs show that many of the most interconnected EU banks (those with the largest number of linkages measured by 
degree centrality) are typically the banks with the largest individual exposures.

In Figure 6, we examine the geography of the exposures of the top twenty-five banks by their exposures to shadow banking entities. While there is some heterogeneity across banks, it is clear the EU banks are heavily exposed to shadow banking entities located outside of the EU. The monitoring of such linkages is particularly challenging if authorities lack an holistic view of banks' and shadow banks' international activities or if they lack information on some aspects of their activities. Moreover, Figure 7 presents a global map of the exposures based on the country of domicile of the shadow banking entity. As highlighted by Lane (2016a), information sharing amongst regulators and policymakers can be an important component in the surveillance of international shadow banking activities.

While our analysis provides a unique insight into the geography of the exposures of EU banks to shadow banking entities, it is subject to a number of limitations. The data underpinning our analysis show the domicile of the shadow banking entity. As noted by Grillet-Aubert et al. (2016) the "country of domicile is important in determining the geographic locus of potential supervisory measures". However, such geographic data are based on a first counterparty basis and may not reflect the ultimate risk bearers within the shadow banking entity. For example, while a shadow banking entity may be domiciled in country A owing to a favourable business or tax environment, the end investor may be located in country B, and therefore such flows of potential risk would not be captured in our analysis. In addition, we lack information on the regulatory treatment of the shadow banking counterparty which would be required to map the cross-border risks in more detail. 


\section{FIGURE 4. Network of EU banks' exposures to shadow banking entities}

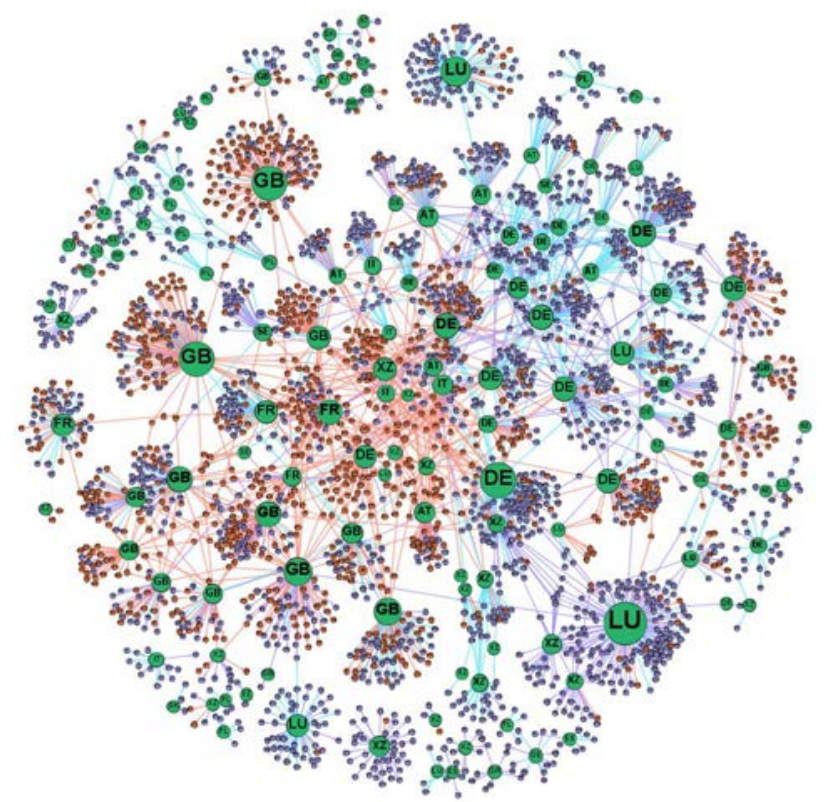

Source: Authors' calculations based on EBA (2015), Report on institutions' exposures to "shadow banking entities", December 2015. Note: Data refer to individual exposures equal to or above 0.25 per cent of institutions' eligible capital. Green nodes: reporting institutions (banks) labelled by country of residence. Purple and orange nodes: EU and non-EU domiciled shadow banking entities, respectively. The chart excludes investment firms and exposures greater than $25 \%$ of the institution's eligible capital (the large exposure limit). Node size is proportional to degree centrality (the number of counterparties). Blue links represent domestic exposures (EU institution to a domestic shadow banking entity); purple links represent EU exposures (EU institution to EU-domiciled shadow banking entity) and orange links represent non-EU exposures (EU institution to non-EU domiciled shadow banking entity)

\section{FIGURE 5. Network of EU banks' exposures to shadow banking entities}

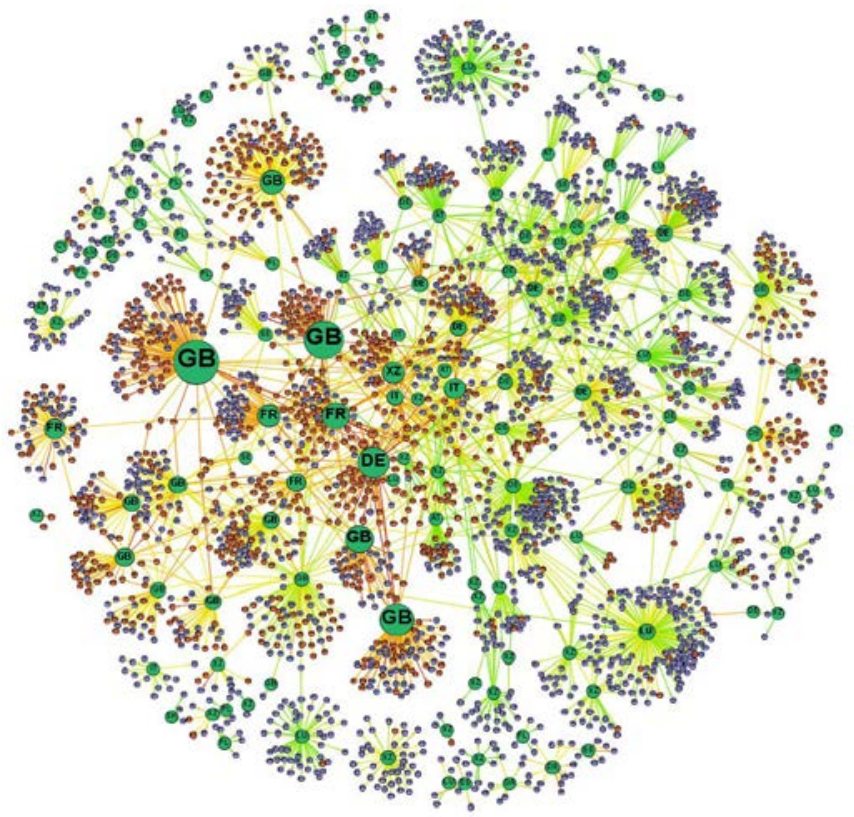

Source: Authors' calculations based on EBA (2015), Report on institutions' exposures to "shadow banking entities", December 2015. Note: Data refer to individual exposures equal to or above 0.25 per cent of institutions' eligible capital. Green nodes: reporting institutions (banks) labelled by country of residence. Purple and orange nodes: EU and non-EU domiciled shadow banking entities, respectively. The chart excludes investment firms and exposures greater than $25 \%$ of the institution's eligible capital (the large exposure limit). Node size is proportional to total exposures (sum of all individual exposures). Colour of link ranges from green to orange depending on the size of the individual exposure (green links: smaller exposures, orange links: larger individual exposures). 
FIGURE 6. Top 25 EU banks by their exposures to shadow banking entities

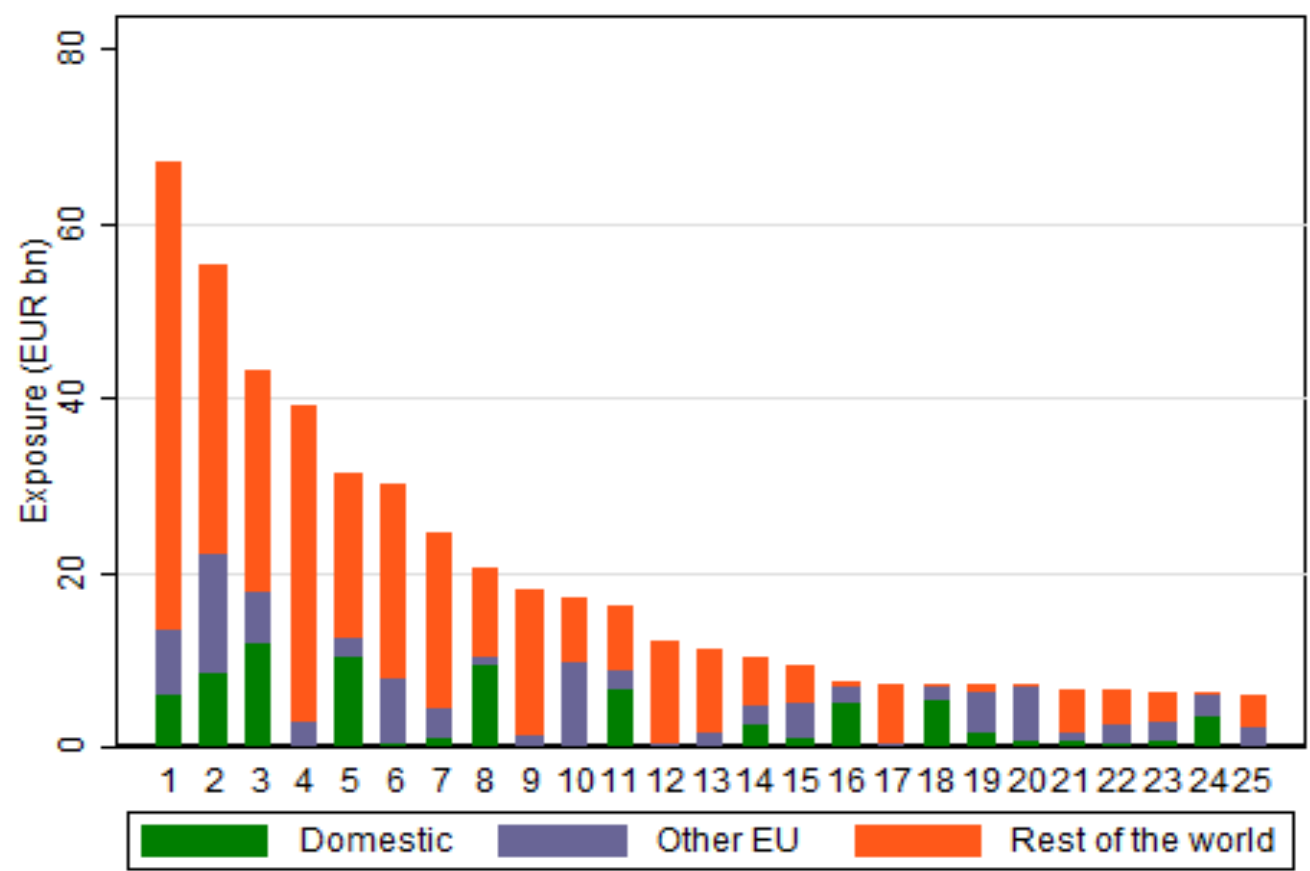

Source: Authors' calculations based on EBA (2015), Report on institutions' exposures to 'shadow banking entities', December 2015. Note: Data refer to individual exposures equal to or above 0.25 per cent of eligible capital. 
FIGURE 7. Geography of risk: distribution of exposures by domicile of shadow banking entities

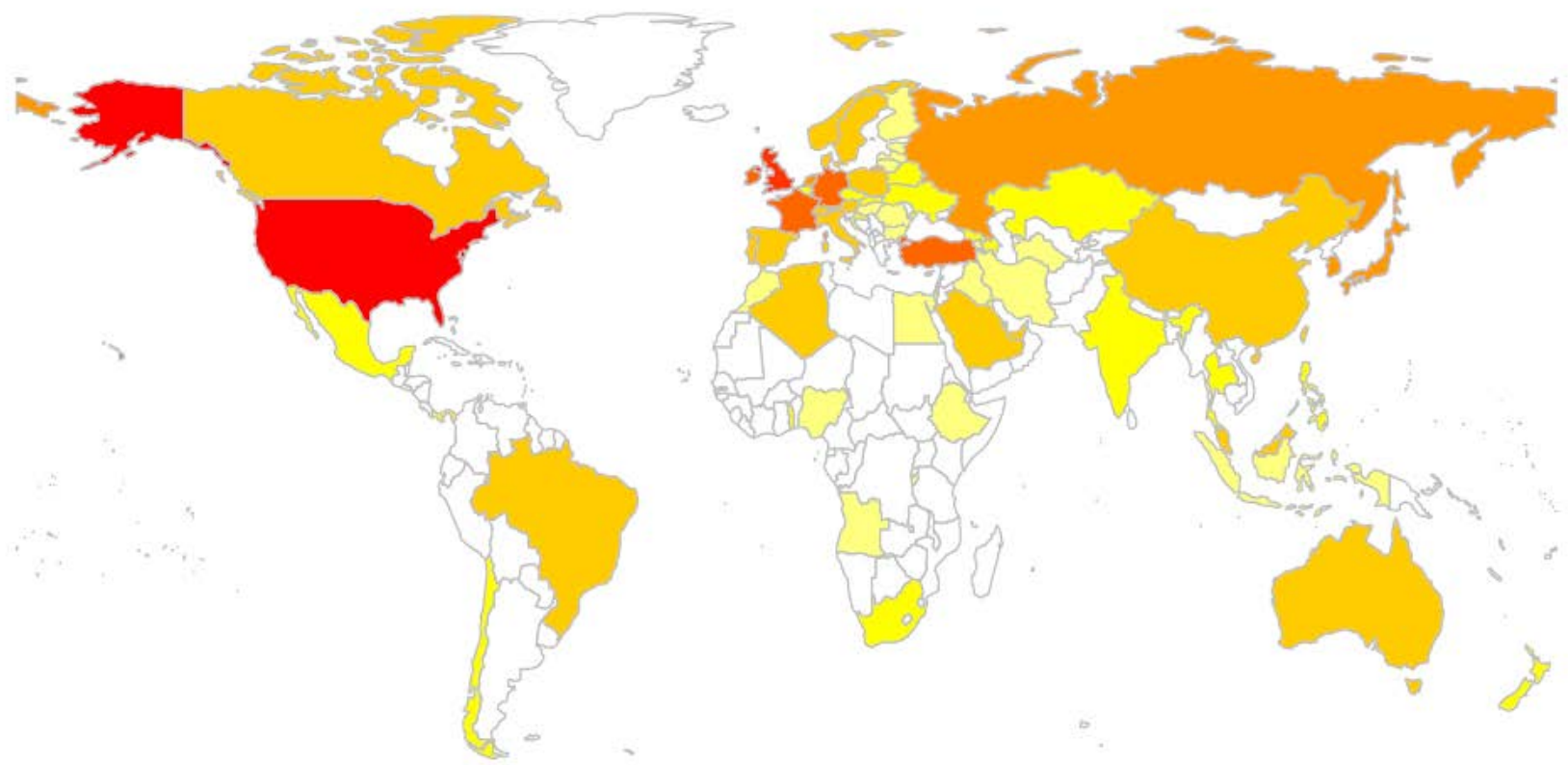

Source: Authors' calculations based on EBA (2015), Report on institutions' exposures to 'shadow banking entities', December 2015. Note: Data refer to individual exposures equal to or above 0.25 per cent of eligible capital. 


\subsection{Concentration / Overlap Analysis}

We now move to analyse to what extent EU banks' exposures to shadow banking entities are concentrated and overlapped. By "overlap", we intend to measure the common exposures of EU banks towards shadow banking entities, and we introduce a specific measure to do so.

There is a natural relationship between concentration and overlap, which we illustrate in the following example, where we analyse three different financial systems composed of 2 banks and 3 shadow banks. For illustrative purposes, for each bank, we consider its portfolio structure as the normalised total exposures (so that they sum up to one).

Example Consider the three financial systems represented by the following portfolio matrices:

$$
\pi^{1}=\left[\begin{array}{lll}
0 & 1 & 0 \\
0 & 0 & 1
\end{array}\right] \quad \pi^{2}=\left[\begin{array}{lll}
0 & 0 & 1 \\
0 & 0 & 1
\end{array}\right] \quad \pi^{3}=\left[\begin{array}{ccc}
1 / 3 & 1 / 3 & 1 / 3 \\
1 / 3 & 1 / 3 & 1 / 3
\end{array}\right]
$$

where the element $\pi_{i k}^{s}$ refers to the exposure from bank $i$ to shadow banking entity $k$ in the $s$-th system.

The first system (matrix $\pi^{1}$ ) presents zero overlap because of the high concentration of the two banks. Each of the banks has no diversification and concentrates its exposures to one entity. A shock to any of the shadow banking entities will not impact the two banks at the same time. The second system (matrix $\pi^{2}$ ) has maximal overlap because of the concentration of its banks. Banks have a concentrated portfolio of exposures (no diversification) but they are both exposed to the same shadow banking entity. A shock to the third shadow banking entity will affect both banks at the same time. The third system, captured by the matrix $\pi^{3}$, presents a completely different picture: the two banks achieve maximal diversification by being exposed to all shadow banking entities in the system. The third system has therefore maximal overlap because of low concentration (maximal diversification) of its banks. Any shock will 
impact equally both banks at the same time.

Overall, this example highlights that the increased diversification of exposures may increase overlap and therefore reduce the benefit of diversification owing to the commonalities of the sources of shocks. In this sense, banking systems may be potentially fragile to certain types of shocks while being robust to others: a system with a high degree of common exposures due to diversification may be resilient to small common shocks, but vulnerable to shocks beyond a specific threshold (see, e.g., Acemoglu et al. 2015). This systemic feature of the financial system has received increased attention in recent years. As financial systems increase their levels of complexity and interconnectedness, they face a trade-off between diversification and systemic risk (Battiston et al., 2012). This stream of research shows that more connections may increase individual diversification while, at the same time, making the system more susceptible to common shocks which may lead to wide-scale systemic failures.

Some studies argue that a certain degree of individual concentration can be beneficial. Stomper (2006), for instance, links concentration to the expertise lenders have in certain sectors. On the other hand, a more locally concentrated system does not benefit from diversification and individual institutions may become riskier. Concentration risk therefore still represents one of the main possible causes of major losses in a credit institution. The global financial crisis brought to light many examples of risk concentrations within financial institutions. Since it can directly affect the survival of an institution, concentration risk requires special attention by supervisors. This has led policymakers to focus specifically on concentration. ${ }^{18}$ Understanding whether overlap is ascribable to either concentration or diversification or both is therefore important from a financial stability perspective.

\subsubsection{Setup}

Hence we seek to understand the type and geography of the shadow banking entities for which overlap occurs, which we hereby analyse. To this end, consider the set of

\footnotetext{
${ }^{18}$ See, e.g., the BIS (BCBS, 2006) and EBA study on Concentration (CEBS Guidelines on the management of concentration risk).
} 
$n$ banks (indexed by $i=1,2, \ldots, n$ ) and the set of the $m$ shadow banks (indexed by $k=1,2, \ldots, m)$. Given an exposure $x_{i k}$ of bank $i$ to shadow bank $k$, the total exposure to shadow banking entities of each bank $i$ is therefore $\sum_{k} x_{i k}$. Further, define the following two ratios:

$$
\pi_{i k}=\frac{\text { exposure of } i \text { to } k}{\text { total shadow bank exposures of } i}=\frac{x_{i k}}{\sum_{k} x_{i k}}
$$

and

$$
l_{i k}=\frac{\text { exposure of } i \text { towards } k}{\text { capital of } i}=\frac{x_{i k}}{c_{i}}
$$

where $\pi_{i k}$ can be thought of as the elements of the portfolio matrix of the system (with $\left.\sum_{k} \pi_{i k}=1, \forall i\right)$, and $l_{i k}$ are individual exposures as a fraction of bank $i$ 's capital. Moreover the total exposure of $i$ as a fraction of its capital is simply given by $l_{i}=\sum_{k} l_{i k}$ and, therefore, it holds that $l_{i k}=l_{i} \times \pi_{i k}$. A simple, yet useful interpretation of the term $l_{i k}$ is the percentage of equity lost by $i$ given a shock on $k$. In this sense, if $l_{i k}>1, i$ may itself default from the default of $k$.

Concentration A well-known measure of concentration is the Herfindahl index (HHI) of concentration, computed in our case as follows:

$$
H_{i}=\sum_{k} \pi_{i k}^{2}
$$

which measures the concentration of the portfolio of exposures to shadow banking entities of bank $i$. The top panel of Figure 8 reports the values of $H_{i}$ for each bank versus their normalised degree (i.e. the number of shadow banking entities to which bank $i$ is exposed). It shows that concentration is inversely related to the number of shadow banking counterparties, i.e. banks with less concentration in their exposures to shadow banking entities also have a larger set of counterparties. The bottom panel of Figure 8 reports the values of $H_{i}$ versus the number of different countries to which each bank is exposed. It suggests that banks with low levels of concentration have their expo- 
sures split across many different countries. This has an important implication for our cross-border analysis if diversification is achieved by having exposures to jurisdictions or sectors where prudential regulation may not apply.

Overlap We focus on a simple measure for portfolio overlap between two banks:

$$
s_{i j}^{\pi}=\sum_{m} \min \left\{\pi_{i m}, \pi_{j m}\right\}
$$

where the index $m$ refers to each of the nine shadow banking categories in our sample (as described in Section 3.2), aggregated by their country of domicile. The quantity $s_{i j}^{\pi}$ can be interpreted as the intersection of the two portfolios, i.e. the common amount of exposures to the same combinations country/type of shadow bank entities. We compute this pairwise quantity for all the banks in our sample. Naturally, given the large number of shadow banking entities in our sample, many banks will have zero overlap, in that they will have no shadow bank exposure in common. It is therefore useful to compute the overlap both conditional on the existence of common exposures and unconditionally. Also, given the granularity of our dataset, we can analyse the levels of overlap at two levels of aggregation: by country of shadow banking entity and by type of shadow banking entity. The results are reported in Figure 9, where we plot the empirical cumulative density functions (ECDF) of the overlaps for these two levels of aggregation. In both cases, the aggregation by type of shadow banking entity provides higher levels of overlap. The conditional overlap (ECDF) on the top panel shows that, once strictly positive overlaps are computed, these overlaps can be high for a relatively large amount of bank pairs. For example the overlap by country is at least 0.6 for ten percent of the bank pairs. An important fraction of banks may therefore be exposed to common shocks originating from the same set of countries.

\subsection{Vulnerability}

Shocks from the shadow banking system may potentially engender distress in the banking sector and can lead to significant losses. To explore this, we build on the 
FIGURE 8. Concentration.
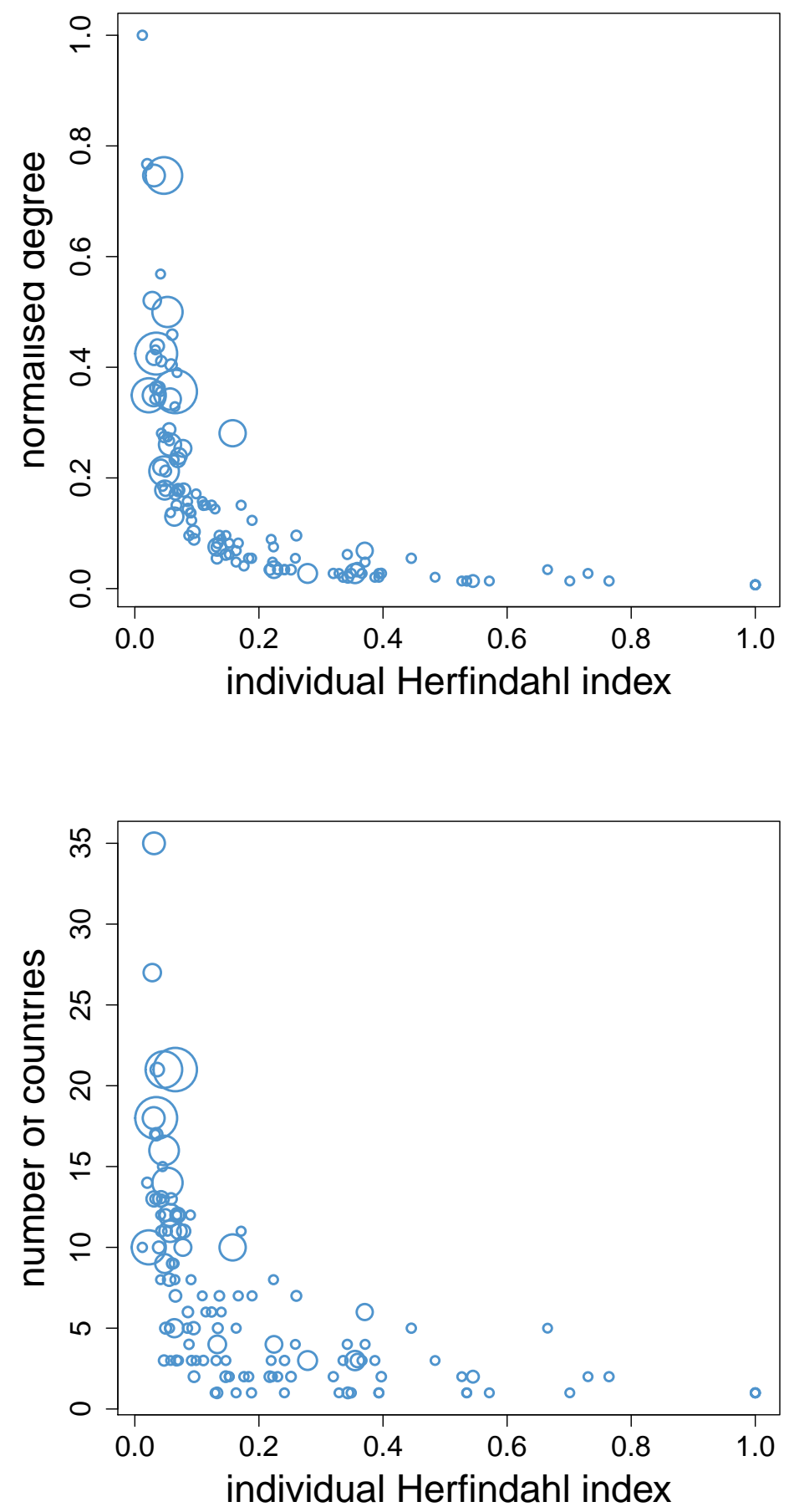

Source: Authors' calculations based on EBA (2015), Report on institutions' exposures to "shadow banking entities", December 2015. Note: the horizontal axes represent concentration indices for each bank as measured by Equation (1). The vertical axes represent normalised degree (top panel) and number of countries to which each bank is exposed (bottom panel). 


\section{FIGURE 9. Overlap.}
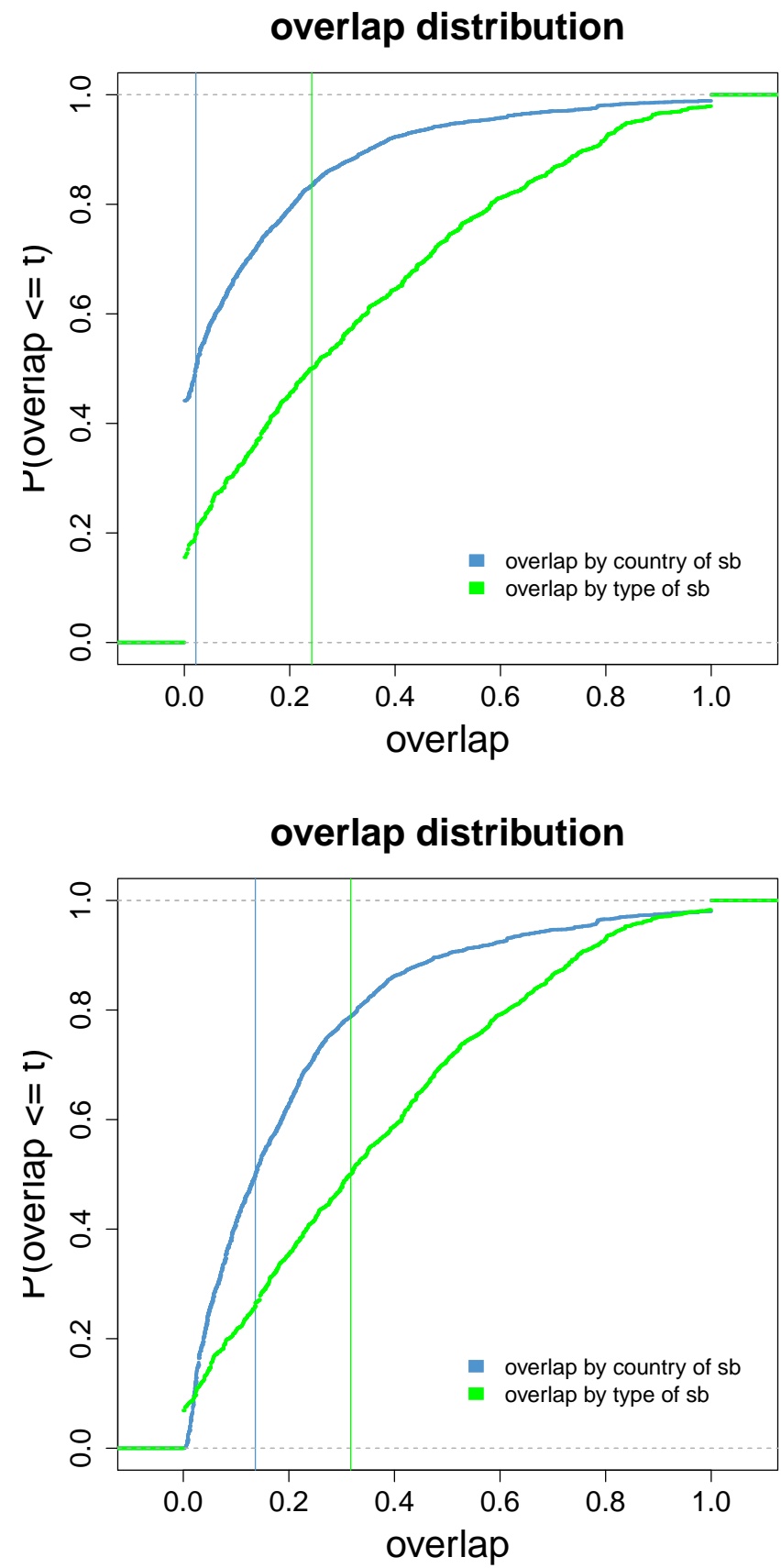

Source: Authors' calculations based on EBA (2015), Report on institutions' exposures to "shadow banking entities", December 2015. Note: empirical cumulative density functions (ECDF) of the overlap measure is computed by Equation (1). Blue lines represent the overlap in terms of countries to which banks are exposed. Green lines represent the overlap in terms of the types of shadow banking entities (as defined in Section 3.2). Top panel: distribution of overlap conditional on the existence of commonalities. Bottom panel: unconditional distribution. 
framework of Battiston et al. (2016) to understand potential capital losses owing to shadow banking activities. First, define the following quantity:

$$
h_{i}=\min \left\{1, \sum_{k} h_{i k}\right\}, \text { where } h_{i k}=l_{i k} r_{k}
$$

which measures the potential relative equity loss due to a shock $r_{k} \in[0,1]$ on a shadow banking entity $k$. The total relative equity loss for the banking system of a country $C$ is:

$$
H_{C}=\min \left\{1, \sum_{i \in C}\left(w_{i} \sum_{k} l_{i k} r_{k}\right)\right\}
$$

where $w_{i}=\frac{c_{i}}{\sum_{j} c_{j}}$ is the relative capital of $i$ with respect to the total aggregate capital in the system.

Within this framework, it is possible to understand what are the types of shadow banking entities, aggregated by their country of domicile, that could lead to the largest losses for the EU banking system, by computing the following quantity:

$$
H_{m}=\min \left\{1, \sum_{i} w_{i} l_{i m} r_{m}\right\}
$$

where $m$ represents one of the nine shadow banking categories in our sample (as described in Section 3.2), aggregated by their country of domicile. By assuming a common shock to all sectors $\left(r_{m}=r, \forall k\right)$, we can rank them in terms of the potential equity loss they would cause in the EU banking system. Table 5 presents the ranking for the top ten results. We observe that finance companies (Type 4) domiciled in the US represent the top source of vulnerability for the EU banking sector, followed by USdomiciled securitisation vehicles (Type 7) and US-domiciled shadow banking entities that could not be further defined or classified as 'other' (Type 9). This shows that the top three largest exposures for the EU banking system are indeed US-domiciled shadow banking entities.

Last, we analyse how these different sources of vulnerability may impact the same 


\begin{tabular}{llll}
\hline Rank & Source & Rank & Source \\
1 & US Finance companies & 6 & DE Non-MMF investment funds \\
2 & US Securitisation & 7 & KY Non-MMF investment funds \\
3 & US 'Other' & 8 & TR Non-equivalent banks/insurers \\
4 & IE Securitisation & 9 & JE Securitisation \\
5 & US Non-MMF investment funds & 10 & GB 'Other' \\
\hline
\end{tabular}

Source: Authors' calculations based on EBA (2015), Report on institutions' exposures to "shadow banking entities", December 2015. Note: Rank of the top ten sources of vulnerability (from highest to lowest) for the EU banking system (in terms of potential equity loss). The sources of vulnerability are shadow banking categories as classified in Section 3.2, aggregated by their country of domicile.

banks by computing a leverage-based overlap measure:

$$
S_{i j}^{l}=\sum_{k} \min \left\{l_{i k}, l_{j k}\right\}
$$

which measures the common relative equity loss to the banking systems of any pair of countries following a given shock. ${ }^{19}$ We plot the network associated to $S_{i j}^{l}$ in Figure 10. The colour of the nodes reflects the level of concentration computed as the Herfindahl index, ranging from blue (smaller concentration) to red (larger concentration). It shows that less concentrated banking systems tend have more overlap: more diversification leads to more overlap between banking systems of different EU countries. Given that a common source of vulnerability is represented by US-domiciled entities, this highlights the potential transmission channels stemming from the US shadow banking system which were exposed during the financial crisis (Maes, 2014).

\footnotetext{
${ }^{19}$ By banking system of a country, we refer to the aggregation of all banks in a given country, weighted by the size of their equity.
} 


\section{FIGURE 10. Common vulnerability overlap: less concentrated systems tend to be more overlapped}

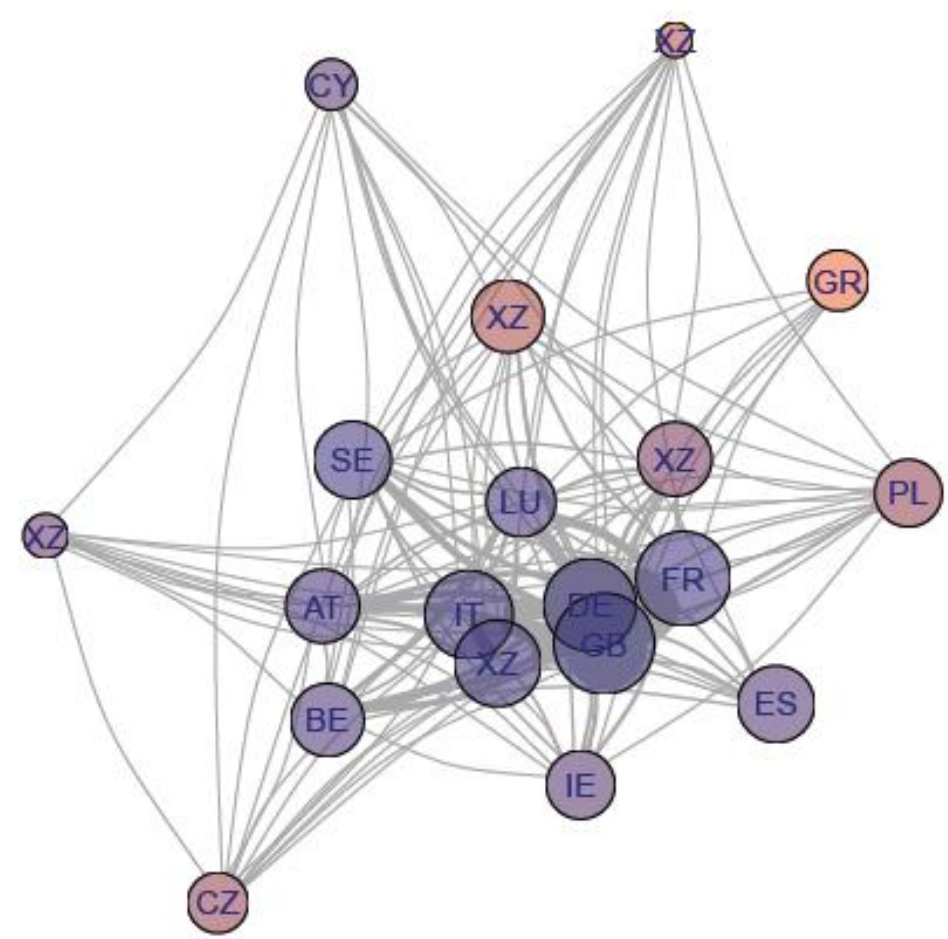

Source: Authors' calculations based on EBA (2015), Report on institutions' exposures to "shadow banking entities", December 2015. Note: each node in the network represents a banking system, defined as the aggregation of the banks by country. The size of the nodes is proportional to the system's total exposures to shadow banking entities. The size of the weights reflects the level of leverage-based overlap as computed in Equation 3. The colour of the nodes reflects the level of concentration computed as the Herfindahl index, ranging from blue (smaller concentration) to red (larger concentration). 


\section{Policy}

Recent policy initiatives such as the Capital Markets Union (CMU) seek to increase the role of market-based finance in the EU financial system but also reinforce the need for detailed monitoring frameworks for the shadow banking system. The global financial crisis highlighted the risks associated with an overbanked financial system (ESRB 2014), while empirical evidence suggests that a heavily bank-based financial system can exert a negative effect on long-run economic growth (Langfield and Pagano 2016). But credit intermediation through lightly regulated or non-regulated non-bank financial institutions can also pose risks to financial stability if left unmonitored.

The potential leakage of bank-like activities outside the regulatory perimeter poses challenges for policymakers and regulators. Regulatory arbitrage - the circumvention of financial regulation or tax or disclosure rules - reduces the overall transparency of the financial system and can lead to the build-up of vulnerabilities. As revealed during the financial crisis, the build-up of systemic risks went unnoticed in less regulated parts of the financial system until it was too late. Even when policymakers and regulators identified these risks, they lacked appropriate data to understand the extent of the linkages across institutions, markets and borders. Therefore, as noted by Cecchetti and Tucker (2016), regulatory arbitrage and the behaviour of institutions and activities which lie outside the regulatory perimeter should be a central consideration in the design of macroprudential regimes aimed to enhance financial stability and secure the resilience of the financial system.

A growing number of studies have highlighted the role of macroprudential policy in mitigating financial stability risks (Borio, 2009., Hanson et al. 2011., Claessens et al, 2013., Schoenmaker and Wierts, 2016). While macroprudential policy in the banking sector in Europe is operational, the toolkit for macroprudential policy beyond the banking sector is still in its infancy. As noted by ESRB (2016b), a broader set of macroprudential instruments can assist in mitigating potential financial stability risks arising from the increased interconnectedness of the financial system. Lane (2016b) posits that the rise of the shadow banking system and the scope for cross-border spillovers and 
substitution effects requires careful coordination of macroprudental policies through authorities such as the ESRB. The importance of international cooperation in the design and implementation of macroprudential policy has also been highlighted by Cecchetti and Tucker (2016). Moreover, recent empirical evidence supports the view that activities can leak across borders and sectors (Claessens et al. 2013., Aiyar et al. 2014., Reinhardt and Sowerbutts. 2015., Cizel et al. 2016).

ESRB (2016b) provides an overview of macroprudential policy options to address risks from non-bank financial institutions and describes existing leverage and liquidity requirements (e.g. UCITS and AIFMD) which have a macroprudential dimension. New regulatory data through the AIFMD, the European Market Infrastructure Regulation (EMIR) and the Securities Financing Transaction Regulation (SFTR) can allow for a more detailed assessment of the interconnectedness of banks and shadow banking entities in a number of markets. These data can also be used to monitor the use of synthetic leverage by non-bank financial institutions and allow for the mapping of linkages between banks and non-banks in derivative markets (Abad et al., 2016; D'Errico et al., 2016).

Recent policy measures can act to enhance the resilience of the financial system and mitigate some of the financial stability risks associated with the increased interconnectedness of the banking and shadow banking systems. For example, the EBA's guidelines on limits on exposures to shadow banking entities, effective from 1 January 2017, introduce an approach that will allow EU institutions to set internal limits for their exposures to shadow banking entities. For those institutions that do not have sufficient information on their exposures to shadow banking counterparties, the EBA requires a fallback approach involving a fixed limit (25\% of eligible capital) to all or some of the aggregated exposures. In addition, limits on concentration of exposures can also assist in mitigating risks across sectors (ESRB, 2016b). 


\section{Conclusions}

The increasing size of the shadow banking system underlines the need for a better understanding of the linkages of shadow banking entities with different parts of the financial system, including the banking system. Despite the increased focus on assessing the interconnectedness between banks and shadow banking entities since the financial crisis, to the best of our knowledge no study documents these linkages using bank- and exposure-level information in Europe. In light of this gap in the literature, this paper examines the exposures of EU banks to shadow banking entities drawing on a unique data collection exercise by the EBA in March 2015.

Our analysis confirms that the exposures of EU banks to shadow banking entities is global and spans regional and national borders. Consistent with the literature, our analysis shows that EU banks have significant exposures to shadow banking entities globally and, in particular, to entities domiciled in the US, which represent approximately $27 \%$ of the total exposures. Moreover, our analysis finds that EU banks' exposures to shadow banking entities are concentrated by type of counterparty, with approximately $65 \%$ of the exposures to securitisations, non-MMF investment funds and finance companies. The global financial crisis showed how such linkages can act as contagion paths and can lead to the amplification of shocks across borders and sectors. Therefore, for the purposes of systemic risk monitoring, our findings further reinforce the need for coordinated responses, which can be facilitated through greater cooperation and information sharing amongst regulators.

We also examine the categories of shadow banking entities that can potentially act as a source of vulnerability to the EU banking system, when the former are grouped by their country of residence and type. When examining the level of concentration and overlap of the exposures, we find that EU banks have low levels of individual concentration towards shadow banking entities. However, this diversification leads to high overlap where different banks are commonly exposed to the same types of shadow banking entity. This high but shared diversification across types of shadow banking entities may potentially lead to common sources of vulnerability in times of 
stress.

Our results also suggest a number of avenues for future research. The analysis in this paper presents EU banks' exposures to shadow banking entities and is therefore based on the asset side of banks' balance sheets. Building on this, future work can seek to investigate the liability side of banks' balance sheets and specifically the role of shadow banking entities as a source of funding for banks. Moreover, understanding the linkages of shadow banking entities to other non-bank financial institutions is also an important part of the financial ecosystem which needs to be monitored. A mapping of these linkages and potential contagion paths between sectors and jurisdictions will provide a more complete picture of the interconnectedness of the banking and shadow banking systems. Other potential areas for further work include an examination of the supervision and regulation of individual shadow banking entities, including their potential prudential consolidation, in order to understand better which entities lie fully outside of the regulatory perimeter. 


\section{References}

Abad, J., Aldasoro, I., Aymanns, C., D’Errico, M., Fache Rousová, L., Hoffmann. P., Langfield, S., Neychev, M., and Roukny, T. (2016), "Shedding light on dark markets: First insights from the new EU-wide derivatives dataset", ESRB Occasional Paper no. 11.

Acemoglu, D., Ozdaglar, A. and Tahbaz-Salehi, A., (2015), "Systemic risk and stability in financial networks", The American Economic Review, 105(2), pp.564-608.

Acharya, V., Schnabl, P. and Suarez, G. (2013), "Securitization without risk transfer", Journal of Financial Economics, 107(3), p. 515-536.

Adrian, T. and Ashcraft, A. B. (2012) "Shadow Banking: A Review of the Literature", FRBNY Staff Reports, No. 580, Federal Reserve Bank of New York.

Adrian, T. Ashcraft, A. B. and Cetorelli, N. (2013), "Shadow Bank Monitoring”, FRBNY Staff Reports, No. 638, Federal Reserve Bank of New York.

Adrian, T. (2014), "Financial Stability Policies for Shadow Banking”, FRBNY Staff Reports, No. 664, Federal Reserve Bank of New York.

Aiyar, S., Calomiris, C.W. and Wieladek, T. (2014), “Does Macro-Prudential Regulation Leak? Evidence from a UK Policy Experiment", Journal of Money, Credit and Banking, Vol. 46(1), pp. 181-214.

Battiston, S., Delli Gati, D. Gallegati, M. Greenwald, B. and Stiglitz, J. (2012), “Liaisons dangereuses: Increasing connectivity, risk sharing, and systemic risk", Journal of Economic Dynamics and Control, 36(8), p. 1121-1141.

Battiston, S., Caldarelli, G., D’Errico, M., and Gurciullo, S. (2016), “Leveraging the network: a stress-test framework based on DebtRank, In: Statistics and Risk Modeling.

Basel Committee on Banking Supervision (2006), "Studies on credit risk concentration", An overview of the issues and a synopsis of the results from the Research 
Task Force project, Working Paper No. 15, Bank for International Settlements, November.

Basel Committee on Banking Supervision (2015), “Consultative Document: Identification and measurement of step-in risk", Bank for International Settlements, December.

Bengtsson, E. (2013), “Shadow banking and financial stability: European money market funds in the global financial crisis", Journal of International Money and Finance, 32, p. $579-594$.

Borio, C. (2009), “The Macroprudential Approach to Regulation and Supervision”, VoxEU, 14 April.

Cecchetti, S. and Tucker, P. (2016), "Is there macroprudential policy without international cooperation?", CEPR Discussion Paper 11042.

Cetorelli, N. (2014), “Hybrid Intermediaries”, FRBNY Staff Report, No. 705, Federal Reserve Bank of New York, December.

Cetorelli, N and Goldberg, L. (2014), "Measures of global bank complexity", Economic Policy Review, Federal Reserve Bank of New York, December, p. 107-126.

Cizel, J., Frost, J., Houben, A. and Wierts, P. (2016), “Effective Macroprudential Policy: Cross-Sector Substitution of Price and Quantity Measures", IMF Working Paper WP/16/94.

Claessens, S., Ghosh, S.R. and Mihet, R. (2013), “Macro-prudential policies to mitigate financial system vulnerabilities," Journal of International Money and Finance, vol. 39(C), pages 153-185.

Claessens, S. and Ratnovski, L. (2014), "What is Shadow Banking?", IMF Working Paper, No. WP/ 14/25. 
Clerc, L., Giovannini, A., Langfield, S., Peltonen, T., Portes, R. and Scheicher, M. (2016), “Indirect contagion: the policy problem", Occasional Paper Series, No. 9, ESRB, January.

Committee of European Banking Supervisors (2010), “CEBS Guidelines on the management of concentration risk under the supervisory review process" (GL31), September.

Covitz, D., Liang, N. and Suarez, G. (2013), “The evolution of a financial crisis: Collapse of the asset-backed commercial paper market", Journal of Finance, 68(3), p. 815-848.

D’Errico, M., Battiston, S., Peltonen, T. and Scheicher, M. (2016), "How does risk flow in the credit default swap market?", ESRB Working Paper Series, No 33, December.

European Banking Authority (2014), "Report to the European Commission on the perimeter of credit institutions established in the Member States", November.

European Banking Authority (2015), “Report on institutions' exposures to shadow banking entities - 2015 data collection", December.

European Systemic Risk Board (2016a), "EU Shadow Banking Monitor”, No 1, July.

European Systemic Risk Board (2016b), “Macroprudential policy beyond banking: an ESRB strategy paper", July.

Financial Stability Board (2011), “Shadow Banking: Strengthening Oversight and Regulation. Recommendations of the Financial Stability Board", October.

Financial Stability Board (2015), “Global Shadow Banking Monitoring Report”, November.

Fischer, S. (2015), “Financial Stability and Shadow Banks: What We Don't Know Could Hurt Us", speech given at the "Financial Stability: Policy Analysis Data Needs" 2015 Financial Stability Conference sponsored by the Federal Reserve Bank of Cleveland and the Office of Financial Research, Washington, D.C. 
Godfrey, B., Killeen, N. and Moloney, K. (2015), “Data Gaps and Shadow Banking: Profiling Special Purpose Vehicles' Activities in Ireland", Quarterly Bulletin Articles, Central Bank of Ireland, pages 48-60, July.

Gornicka, L. A. (2016), “Banks and shadow banks: Competitors or complements?’, Journal of Financial Intermediation, 27, p. 118-131.

Grillet-Aubert, L., Haquin, J.-B., Jackson, C., Killeen, N. and Weistroffer, C. (2016), "Assessing shadow banking - non-bank financial intermediation in Europe", Occasional Paper Series, No. 10, ESRB, July.

Hanson, S., Kayshap, A., and Stein, J. (2011), “A macroprudential approach to financial regulation", Journal of Economic Perspectives, 25(1), 3-28, Winter.

International Monetary Fund (2014), “Global Financial Stability Report”, October.

Lane, P. (2016a), Address by Governor Philip R. Lane to the International Capital Market Association Conference, May.

Lane, P. (2016b), “Macro-financial stability under EMU”, ESRB Working Paper Series, No. 1, February.

Langfield, S. and Pagano, M. (2016), “Bank bias in Europe: Effects on systemic risk and growth", Economic Policy, 31(85), p. 51-106.

Maes, S. (2014), "Shadow Banking: a European perspective”, Proceedings of the Federal Reserve Bank of Chicago 16th Annual International Banking Conference.

Pagano M, Langfield, S., Acharya, V., Boot, A., Brunnermeier, M., Buch, C., Hellwig, M., Sapir, A., and van den Burg, I. (2014), “Is Europe overbanked?” Report No.4 of the ESRB's Advisory Scientific Committee.

Pozsar, Z., Adrian, T., Ashcraft, A. and Boesky, H. (2013), "Shadow Banking”, Economic Policy Review, Federal Reserve Bank of New York, p. 1-16, December. 
Reinhardt, D. and Sowerbutts, R. (2015), "Regulatory arbitrage in action: evidence from banking flows and macroprudential policy", Bank of England Staff Working Paper No. 546.

Schoenmaker, D. and Wierts, P. (2016), “Macroprudential supervision: From theory to policy", ESRB Working Paper Series, No. 2, February.

Stomper, A. (2006), "A Theory of Banks' Industry Expertise, Market Power, and Credit Risk", Management Science, 52, p. 1618-1633. 